\title{
Utilizing 'hot words' in ParaConc to verify lexical simplification strategies in English-Xhosa parallel texts
}

\author{
Koliswa Moropa \\ Department of Linguistics, University of South Africa \\ P.O. Box 392, UNISA 0003, Pretoria, Republic of South Africa \\ moropck@unisa.ac.za
}

\begin{abstract}
The aim of this article is to illustrate that ParaConc, a parallel concordancer designed by Barlow (1995) has proved useful in the analysis of parallel texts, i.e. source texts (ST) and their target texts (TT), which are English original texts and their Xhosa translated versions respectively in this context. The 'hot word' function in ParaConc has been used to verify the use of simplification strategies by translators during the translation process. Both stylistic and lexical simplification strategies are noticeable in the EnglishXhosa parallel texts under study, but the focal point here is lexical simplification. Lexical simplification strategies investigated are: using a superordinate or more general word, using a general word with extended meaning and using more familiar or common synonyms. The analysis gives the reader an idea about how some general words are used to translate technical language. It also displays that 'hot words' in ParaConc in most instances do indeed include translations of the search word, if the texts are aligned properly.
\end{abstract}

\section{Introduction}

A general idea of how ParaConc (Parallel Concordancer) functions is elucidated in the introductory section of this article, and screenshots illustrating the search and selection of 'hot words' are provided as part of the methodology. Thereafter, the evidence of simplification in translated texts, as observed by Laviosa-Braithwaite (1996, 1997), is sketched out. This is followed by the analysis of three simplification strategies in particular, using a superordinate or more general word, using a general word with extended meaning and using more familiar or common synonyms. Paraphrasing, the fourth simplification strategy which has been identified in the parallel texts, is not considered in this article. This simplification strategy has been discussed extensively as a term-formation process (cf. Moropa, 2007:198-199).

\section{Searching for hot words in ParaConc}

ParaConc is a parallel concordancer which, according to Barlow (1995:1), 'involves searching for the forms within one language that convey the meaning that the user wants to express or investigate in a second language'. A detailed discussion on ParaConc and the alignment process is found in Moropa (2007:188-190). The hot word function in ParaConc suggests possible translations and other associated words: Barlow (2002:22) writes as follows about hot words:

To select words as hot words, the program looks at the frequency of each word in the results window and ranks the words according to the extent to which the observed frequency deviates from expected frequency based on the original corpus. The words at the top of the list might include [own emphasis] translations of the search word, translations of the collocates of the search word, and collocations of the search word.

The parallel texts which are investigated in this article comprise the following English texts and their translated Xhosa versions.

- The 1997 Annual Report of the Department of Arts, Culture, Science and Technology (DACST) published in 1998.

- A Short Guide to the White Paper on Local Government (1998).

- The 2001/2002 Pan South African Language Board (PanSALB) Financial Statements. 
These texts form part of a larger corpus, i.e. the English-Xhosa Parallel Corpus designed by Moropa (2005) for her doctoral research.

When analysing texts, the first step is to load the parallel texts which have been saved as text files in a workspace created in ParaConc. Then the texts are aligned, preferably at sentence level, before any search is conducted. The following figure is an example of an alignment at sentence level.

Figure 1: Texts aligned at sentence level - The 1997 DACST Annual Report

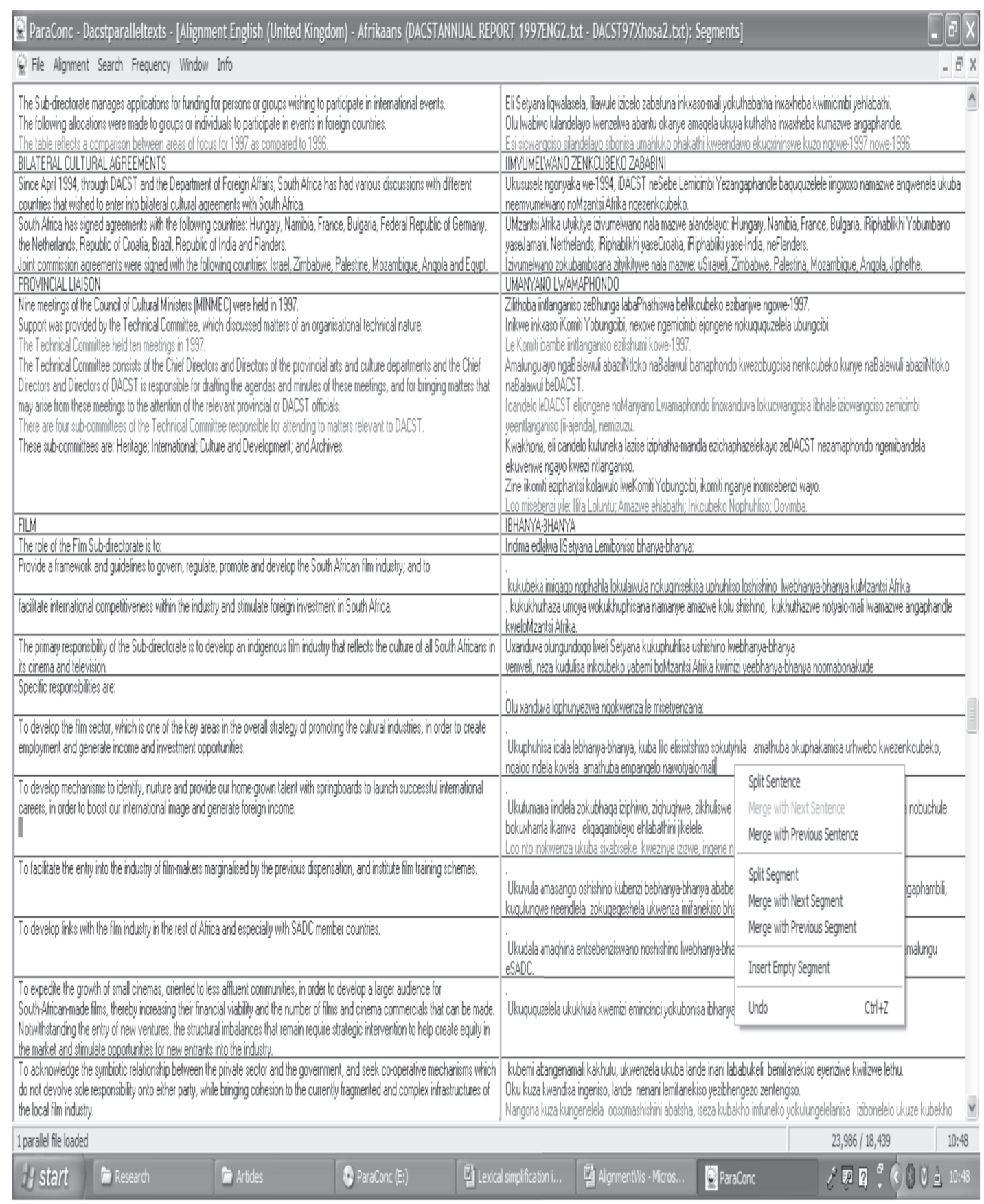

It should be noted that, since Xhosa does not appear in the list of languages listed in ParaConc, Afrikaans is used as a 'label'. After the texts have been aligned, the next step is to click the 'advanced search' command on the menu, and then enter the pattern. Here, the term 'pattern' refers to the search word (cf. Figure 2). 
Figure 2: Advanced search in ParaConc

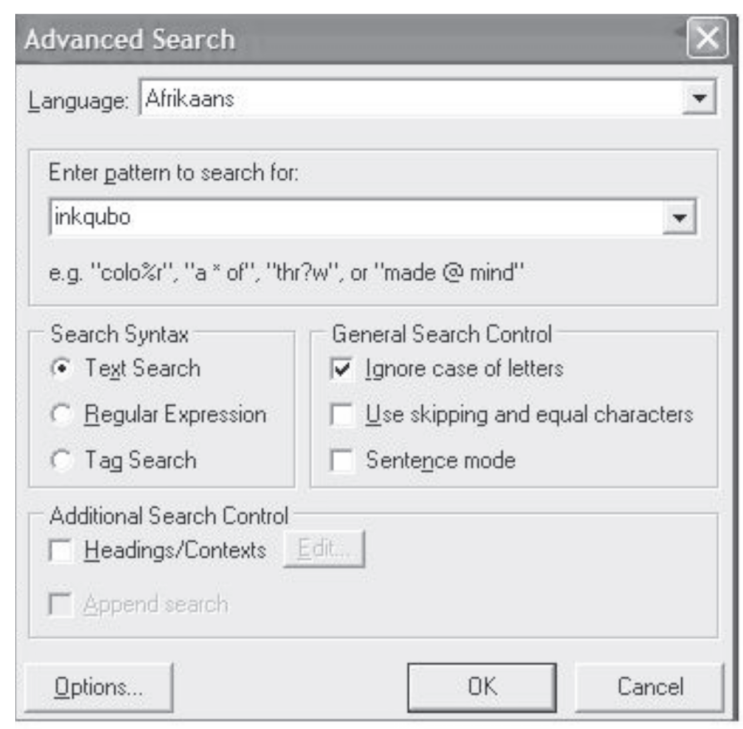

After obtaining the concordance lines, which are displayed on the upper window, the right click on the lower window creates a small dialogue box, with 'hot words' as one of the commands (cf. Figure 3, below).

Figure 3: Hot word query

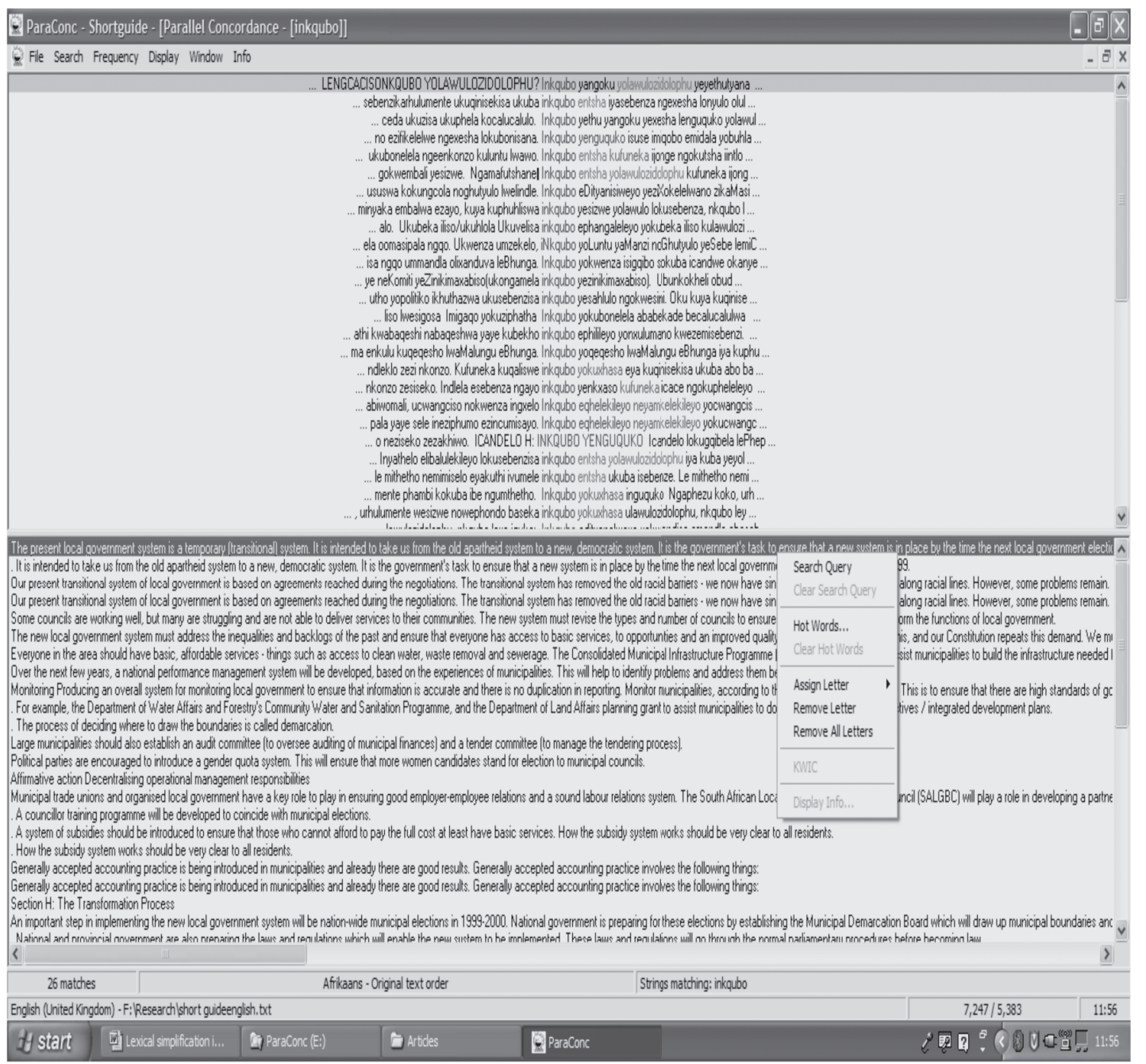


The results are obtained by clicking on 'hot words' in the small dialogue box in the lower window and the hot word list appears, as shown in Figure 4.

Figure 4: Hot word list

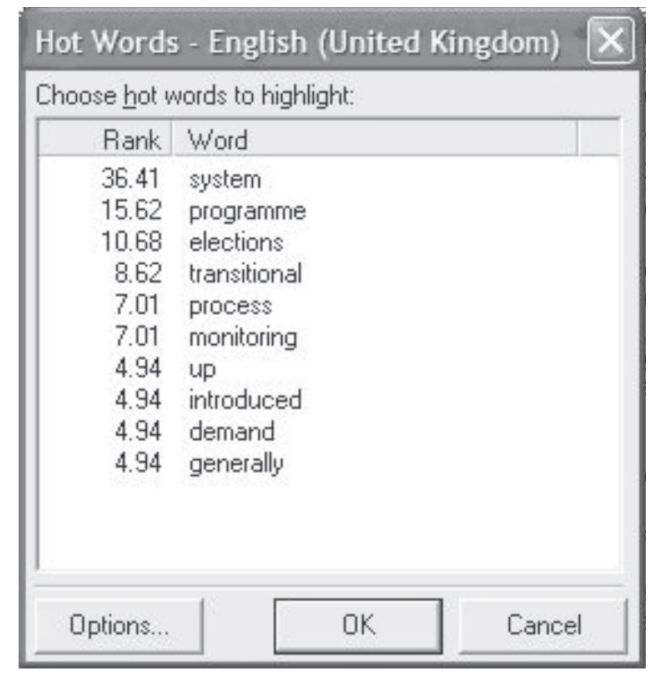

If the texts are aligned properly, one is likely to get rewarding results. For example, the pattern entered in Figure 2 is inkqubo, and the results in Figure 4 show 'system' and 'programme' as the highest ranking words in the hot word list.

When the word has a low frequency, the parallel concordancer is unable to select hot words. The response is: 'There are not enough matches. Check options' (cf. Figure 5 below). The researcher is referred to the paradigm option because this option promotes 'a higher ranking of those words whose form resembles other words in the ranked list' (Barlow, 2002:22).

Figure 5: Not enough matches

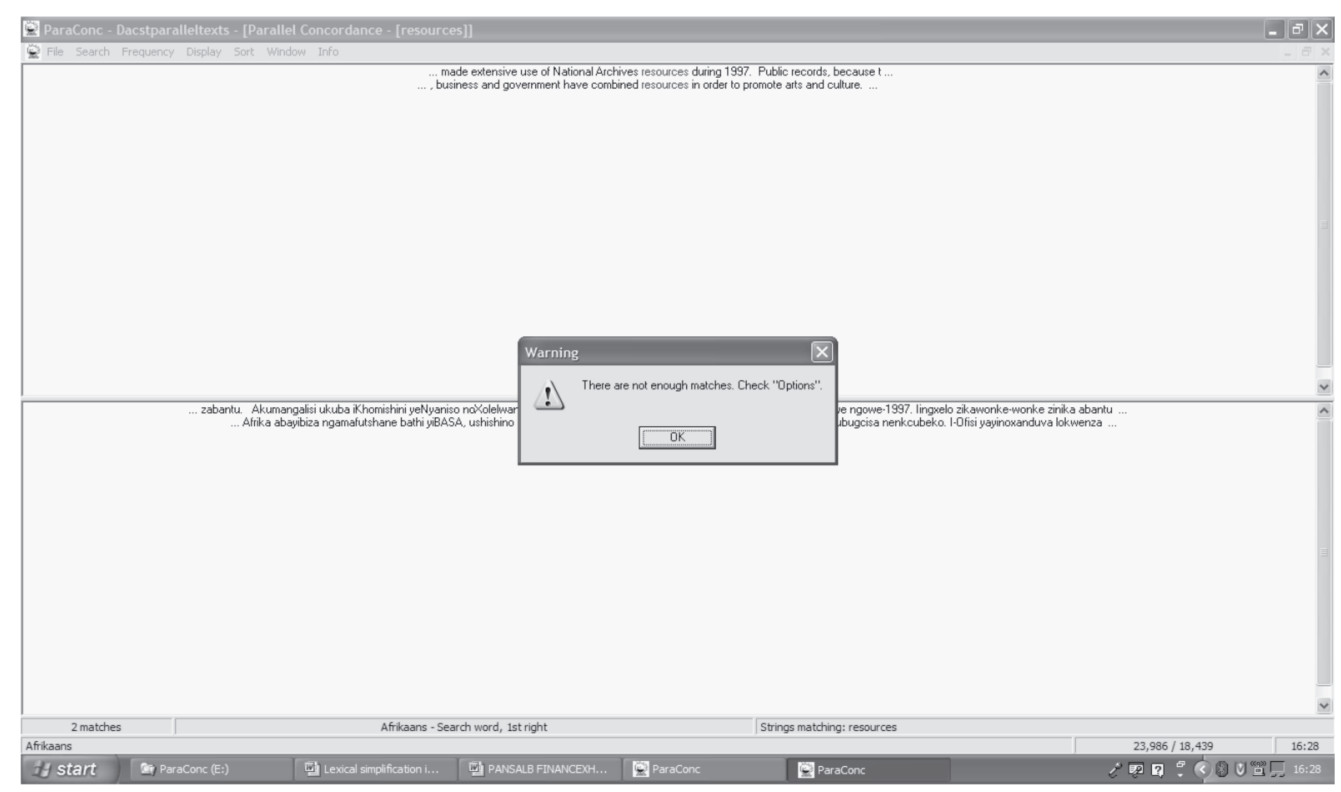


In this section, it was illustrated how hot words are searched by means of ParaConc. The hot word list in Figure 4 demonstrates that the words at the top of the list might include translations of the search word (cf. Barlow, 2002). Although the focal point in this article is lexical simplification, in the next paragraphs a general outline of simplification in translation, as expounded by Laviosa-Braithwaite $(1996,1997)$, is presented.

\section{Simplification in translated texts}

Simplification can be defined as the translator's attempt to make the language of translation more easily understood by the reader. According to Baker (1996:182), simplification involves making things easier for the reader. It raises the level of explicitness by resolving ambiguity. Laviosa-Braithwaite (1996) investigated simplification hypotheses in two sub-corpora of the English Comparable Corpus (ECC), namely the Newspaper sub-corpus of The Guardian and The European collections on the one hand and Narrative sub-corpus on the other. In her investigation, using WordSmith Tools, she examined type-token ratio, lexical density and sentence length. With regard to The Guardian collection, Laviosa-Braithwaite (1996) observed that the Translated English Corpus (TEC) texts appeared to show a higher level of simplification than the comparable NON-TEC texts in respect of the grammatical versus lexical words used, the percentage of high frequency versus low frequency vocabulary and the average sentence length. The Guardian TEC had a lower type-token ratio than The Guardian NON-TEC, but the difference was not statistically significant. Both lexical density and mean sentence length were lower in The Guardian TEC and statistically, the differences were highly significant. The TEC and NON-TEC differed in the relative position of some of their most frequent words, for example, the use of the auxiliary verbs 'to be' and 'to have'. In the TEC texts, the present tense was used more often, while the NON-TEC texts used the past tense more frequently. The results found in The European newspaper articles were consistent with those found in The Guardian articles.

The results concerning the Narrative Prose sub-corpus revealed that the measure of lexical density was the same as in the Newspaper sub-corpus, while the mean sentence length was higher in the Narrative Prose TEC than in the Narrative Prose NON-TEC. On average, the proportion of high frequency words used was higher in the narrative TEC than in the narrative NON-TEC. There was also no clear pattern with regard to the use of the auxiliary verbs 'to have' and 'to be' versus the past tense. The regular features of simplification which characterized both the Newspaper and the Narrative sub-corpora are summed up by Laviosa-Braithwaite (1996:147) as follows:

- Translated texts have a relatively lower percentage of content words versus grammatical words (i.e. their lexical density is lower)

- The proportion of high frequency words versus low frequency words is relatively higher in translated texts

- The list heads in respect of the corpus of translated texts account for a larger area of the corpus

- The list heads of translated texts contain fewer lemmas.

Laviosa-Braithwaite (1997:533) reports that evidence of at least three types of simplification have been found in translated texts, namely syntactic, stylistic and lexical. According to Blum-Kulka and Levenston (in LaviosaBraithwaite, 1997:533), lexical simplification operates according to six micro-textual principles or translation strategies at word level to deal with various types of non-equivalence. These translation strategies are:

1. Use of superordinate terms when there are no equivalent hyponyms in the target language.

2. Approximation of the concept expressed in the source language text.

3. Use of common-level or familiar synonyms.

4. Transfer of all the functions of a source word to its target language equivalent.

5. Use of circumlocutions in place of conceptually matching high level words or expressions, especially with theological, culture-specific or technical terms.

6. Use of paraphrase where there are cultural gaps between the source and the target languages.

In interpreting the findings in this analysis, I refer to the English monolingual dictionaries selected randomly, such as the Collins Concise Dictionary (2001), the World Book Dictionary (Barnhart \& Barnhart, 1992) and The Pen- 
guin English Dictionary (1985), to establish the suitability of the translation used in the target text. I also compare some of the translations, where applicable, to terms and definitions found in The greater dictionary of Xhosa (Pahl, Pienaar \& Ndungane, 1989) and The greater dictionary of Xhosa (Mini, Tshabe, Shoba \& van der Westhuizen, 2003) to see if the translators were guided by these dictionaries in their choice of terms. The two volumes of The greater dictionary of Xhosa $(1989,2003)$ give a number of equivalents which are contextualized. I also use the English source text of The Constitution of the Republic of South Africa and its translated Xhosa version UmGaqosiseko weRiphablikhi yoMzantsi Afrika (1996), because terms in the parallel texts are in context and the constitution is a published and accepted document. Although the translated version has its own shortcomings, I use it as a model.

In the translated texts, the translator makes the language less complicated by using the following simplification strategies: using a superordinate or more general word, using a general word with extended meaning, using more familiar or common synonyms and translating by paraphrase. As already mentioned in the introduction, paraphrasing which has been discussed extensively as a term-formation process by Moropa (2007), is not taken into account in the following investigation.

The next three sections focus on the investigation of lexical simplification in the parallel texts under study. The findings are presented in table format, showing both the source language (SL) and the target language (TL), and the summary of the results indicating the ranks of hot words (cf. Figure 4) derived from ParaConc is provided in the Appendix.

\section{Using a superordinate or a more general word}

Baker (1992:26) isolates the use of superordinates as one of the commonest strategies for dealing with many types of non-equivalence at word level. She mentions that in most languages, if not all, the use of a more general word works well, since the hierarchical structure of semantic fields is not language-specific. What the translators do is to look for a more general word that covers the core propositional meaning of the missing hyponym in the TL. This strategy helps to overcome a relative lack of specificity in the target language compared to the source language. In general, Xhosa lacks specific terms when compared to English.

\section{action/approach/policy/process/system/practice/programme/> inkqubo}

In no less than seven instances, different terms in English were translated using one general word in Xhosa. According to the Collins Concise Dictionary (2001), action is 'the state or process of doing something', approach is 'a means adopted in tackling a problem', policy is 'a plan of action adopted or pursued by an individual, government, party or business', process is 'a method of doing or producing something' and system is defined as 'a method or complex of methods'.

In the Penguin English Dictionary (1985), practice is defined as 'a manner or method of doing something', programme is 'a systematic plan of action'. The meanings of the seven SL words show some similarities, as 'plan of action', 'method' and 'method of doing something' are common explanatory phrases which form part of each definition. Inkqubo is a noun formed from the verb -qhuba which means 'proceed'. Inkqubo has been used by the majority of translators to translate 'practice', 'process', 'system' and 'programme' (cf. Table 1 below). The translators of The Constitution of the Republic of South Africa (1996) also used inkqubo to translate 'process', 'system' and 'practice'. 
Table 1: action/approach/policy/practice/process/programme/system > inkqubo

\begin{tabular}{|c|c|}
\hline Source text & Target text \\
\hline $\begin{array}{l}\text { Action/approach/policy/practice/proceeding(s)/process/programme/ } \\
\text { system }\end{array}$ & Inkqubo 'procedure/process' \\
\hline \multicolumn{2}{|l|}{ 1. action Short Guide (1998) } \\
\hline $\begin{array}{l}\text { Affirmative action: Decentralising operational management responsi- } \\
\text { bilities }\end{array}$ & $\begin{array}{l}\text { Inkqubo yokubonelela ababekade becalulwa: Ukwaba } \\
\text { amagunya oxanduva lwenkqubela yobuphathi. }\end{array}$ \\
\hline \multicolumn{2}{|l|}{ 2. approach DACST (1998) } \\
\hline $\begin{array}{l}\text { A strong driving force behind this approach was the recognition that } \\
\text { an important determinant of the Foresight project would be the high } \\
\text { level ... }\end{array}$ & $\begin{array}{l}\text { Umnqweno omkhulu ondulule le nkqubo yaba kuku- } \\
\text { nakana ukuba isiqinisekiso esomeleleyo sempumelelo } \\
\text { yephulo labaCebi siya kuba kumgangatho ophakami- } \\
\text { leyo ... }\end{array}$ \\
\hline \multicolumn{2}{|l|}{ 3. policy DACST (1998) } \\
\hline $\begin{array}{l}\text { The Sub-directorate is currently guided by the government's foreign } \\
\text { policy, ... }\end{array}$ & $\begin{array}{l}\text { Eli Setyana ngoku likhokelwa yinkqubo karhulumente } \\
\text { yamazwe angaphandle, ... }\end{array}$ \\
\hline \multicolumn{2}{|l|}{ 4. practice Short Guide (1998) } \\
\hline Generally accepted accounting practice is being introduced & $\begin{array}{l}\text { Inkqubo eqhelekileyo neyamkelekileyo yocwangciso } \\
\text { iyaqalwa }\end{array}$ \\
\hline \multicolumn{2}{|l|}{ 5. process DACST (1998) } \\
\hline $\begin{array}{l}\text { Prior to the appointment of this company, the Directorate had facili- } \\
\text { tated the process of appointing a design agency to design a logo for } \\
\text { the conference }\end{array}$ & $\begin{array}{l}\text { Phambi konyulo lwale nkampani, i-Ofisi yalungisa } \\
\text { inkqubo yokonyula unozakuzaku oza kuyila ilogo } \\
\text { yenkomfa }\end{array}$ \\
\hline \multicolumn{2}{|l|}{ 6. programme Short Guide (1998) } \\
\hline $\begin{array}{l}\text { Since 1997, these transfers have been made through Consolidated } \\
\text { Municipal Infrastructure Programme. }\end{array}$ & $\begin{array}{l}\text { Ukusuka kowe-1997, olu dluliselo lwemali belusenziwa } \\
\text { ngeNkqubo eDibeneyo yeziSeko zikaMasipala. }\end{array}$ \\
\hline \multicolumn{2}{|l|}{ 7. system Short Guide (1998) } \\
\hline $\begin{array}{l}\text { Local government is just one part of a new cooperative system of } \\
\text { government in South Africa }\end{array}$ & \begin{tabular}{|l} 
Ulawulozidolophu yenye nje inxalenye yenkqubo yo- \\
manyano yorhulumente eMzantsi Afrika. \\
\end{tabular} \\
\hline \multicolumn{2}{|l|}{ System DACST (1998) } \\
\hline Science, engineering and technology (system configuration) & $\begin{array}{l}\text { Ukuhlolwa kwamaZiko ezenzululwazi, ubunjineli nobu- } \\
\text { chwepheshe (isimo senkqubo) }\end{array}$ \\
\hline
\end{tabular}

\section{approach/process/strategy/system > i(i)ndlela}

In Table 2 below, approach, process, system and strategy are translated by a general word indlela. Indlela means 'way', 'method' or 'manner'. The terms approach, process and system are also translated as inkqubo, as illustrated in Table 1. Inkqubo is more expressive than indlela. The noun inkqubo is derived from the verb -qhuba 'to proceed', 'to go ahead', 'to be engaged in an activity', 'to follow a certain method', 'to drive, urge, exhort (people) to get on with a task', etc., and indlela is a common noun meaning 'way/path/road'.

Table 2: approach/strategy/system > i(i)ndlela

\begin{tabular}{|c|c|}
\hline Source text & Target text \\
\hline Approach/process/strategy/system & I(indlela) 'way(s)' \\
\hline \multicolumn{2}{|l|}{ 1. approaches Short Guide (1998) } \\
\hline $\begin{array}{l}\text { Section F of the White Paper proposes creative approaches to } \\
\text { extend basic services ... }\end{array}$ & $\begin{array}{l}\text { Icandelo F lePhepha leNgcacisonkqubo liphakamisa iindlela } \\
\text { zokusungula ukwandisa iinkonzo zesiseko ... }\end{array}$ \\
\hline \multicolumn{2}{|l|}{ 2. strategies DACST (1998) } \\
\hline $\begin{array}{l}\ldots \text { a comprehensive survey of central government strategies } \\
\text { supporting provincial goals and strategies was undertaken by the } \\
\text { Department of Trade and Industry. }\end{array}$ & $\begin{array}{l}\text {...uphando olunzulu lweendlela zikarhulumente omkhulu ezixhasa } \\
\text { iinjongo neendlela zamaphondo lwenziwa liSebe lezoRhwebo } \\
\text { noShishino. }\end{array}$ \\
\hline \multicolumn{2}{|l|}{ 3. system Short Guide (1998) } \\
\hline $\begin{array}{l}\text { Steps will be taken to improve the system of payment to rural } \\
\text { municipalities. }\end{array}$ & $\begin{array}{l}\text { Kuza kwenziwa iinzame zokuphucula indlela yokuhlawula oomasi- } \\
\text { pala basemaphandleni. }\end{array}$ \\
\hline
\end{tabular}


policy > umgaqo

Policy is translated by means of umgaqo 'method' in the 1997 DACST Annual Report. The translators of the 1997 DACST Annual Report used both inkqubo and umgaqo for policy.

Table 3: policy > umgaqo

\begin{tabular}{|l|l|}
\hline Source text & Target text \\
\hline Policy & umgaqo 'method' \\
\hline 1.policy DACST (1998) & \\
\hline $\begin{array}{l}\text {...communication handbook has been } \\
\text { written and a policy on the use of the DACST logo ... }\end{array}$ & $\begin{array}{l}\text {... incwadana yonxibelelwano sele ibhaliwe kwaye umgaqo on- } \\
\text { gokusetyenziswa kwelogo ... }\end{array}$ \\
\hline
\end{tabular}

In contrast, in The Constitution of the Republic of South Africa (1996) policy is translated by a compound noun inkqubo-sikhokelo. See the following examples:

- ST: may not be exercised in a way that materially and unreasonably prejudices national economic policies, ...

- TT: malingasetyenziswa ngendlela eya kubeka ebubini ngokuphathekayo nangokungaqiqiyo iinkqubozikhokelo zezoqoqosho zesizwe, ...

In a literal sense, iinkqubo-zikhokelo means 'proceedings that are guidelines'.

$$
\text { association/body/organization(s) > um(imi)butho }
$$

Umbutho is a noun formed from the verb -butha which means 'to gather' or 'to collect'. The three words association, organization and body refer to 'a group of people having a common purpose or interest, a society or club'.

Table 4: association/body/organization(s) > um(imi)butho

\begin{tabular}{|c|c|}
\hline Source text & Target text \\
\hline Association/body/organization(s) & Um(imi)butho 'association(s)' \\
\hline \multicolumn{2}{|l|}{ 1. association DACST (1998) } \\
\hline $\begin{array}{l}\text { The International Porcelain Painter's Association of South Africa } \\
\text { received funding ... }\end{array}$ & $\begin{array}{l}\text { Umbutho Wehlabathi Wabazobi Bezinto Zethambo kweloMzantsi } \\
\text { Afrika nawo wafumana inkxaso-mali ... }\end{array}$ \\
\hline \multicolumn{2}{|l|}{ 2. body DACST (1998) } \\
\hline $\begin{array}{l}\text { The Crafts Action Body (CAB) received funding to set up provincial } \\
\text { co-ordinators ... }\end{array}$ & $\begin{array}{l}\text { Umbutho Wemisebenzi Yezandla wafumana imali ukwenzela ukuba } \\
\text { kusekwe abaququzeleli ... }\end{array}$ \\
\hline \multicolumn{2}{|l|}{ 3. bodies Short Guide (1998) } \\
\hline $\begin{array}{l}\text { These are partnerships between the municipality and other public } \\
\text { sector bodies. }\end{array}$ & $\begin{array}{l}\text { Ezi ziimanyano phakathi koomasipala neminye imibutho yecandelo } \\
\text { loburhulumente. }\end{array}$ \\
\hline \multicolumn{2}{|l|}{ 4. organisations DACST (1998) } \\
\hline $\begin{array}{l}\ldots \text { and was presented in cooperation with other arts organisations } \\
\text { such as the Bartel Trust Centre, } . .\end{array}$ & $\begin{array}{l}\text {...kwaye lisebenzisana neminye imibutho yamagcisa njengeziko } \\
\text { ekuthiwa yiBartel Trust Centre, ... }\end{array}$ \\
\hline
\end{tabular}

\section{Using a general word with extended meaning/'Re-designation’}

Some general words are transferred into technical language and are used with a different and more specialized meaning. Aitchison (1994:144) defines the addition of a new meaning to an existing word as 're-designation'. Satyo $(1981: 52,54)$, who refers to the new meanings acquired by these words as amahlumela, which, in a literal sense, means 'young sprouts from an old stalk or tree', writes as follows:

Amagama amaninzi esiXhoseni athi eneentsingiselo zawo zentsusa nje abe nohlohlo lweentsingiselo ezingamahlumela [own emphasis]. Le nto isichumisa ngokukodwa isiXhosa. Ukukhuliswa kwamahlumela eentsingiselo kukukhula kwesiXhosa. Ulwimi asinto imi ndaweninye. Yinto ehleli ikhula mihla le. Amava esizwe nawo ahleli ekhula njengokuba sisiya sidibana nezinye izizwe nje. 
Ekudibaneni kwethu nezinye izizwe sifika sihlangane nezinto ebesikade singenazo kufuneke sizithiye amagama kuba nathi siyazisebenzisa. Sinakho ke nokuthi kumagama abehleli ekho esetyenziswa, sisuke ke songeze intsingiselo yale nto intsha sifuna ukuyithiya igama. Loo nto ke nayo siya kuyenza kuba kukho unxibelelwano oluthile phakathi kwezo ntsingiselo zimbini.

\begin{abstract}
'Many words in Xhosa with their original meanings also acquire a number of other meanings, which are sprouts. This enriches the Xhosa language in a very special way. The growth of other sprouts of meanings means the growth of Xhosa. Language is not static. It grows every day. The experiences of a nation grow as we interact with other nations. When we interact with other nations we encounter items which we did not have in the past and we have to give those items names because we also use them. We can give new meanings to words that we have been using. We can do that because there is a relationship between the two meanings.'
\end{abstract}

Satyo (1981:55) points out that the new meaning springs from the original meaning and the relationship between these two meanings does not fade. In discussing the findings, I verify the suitability of the extended meanings by referring to The greater dictionary of Xhosa (Pahl et al., 1989 \& Mini et al., 2003 respectively), a trilingual dictionary which gives translations of Xhosa words in English and Afrikaans.

\title{
academy/bureau/centre/institute/institution(s)/unit > i(ama)ziko
}

In the Collins Concise Dictionary (2001), academy is defined as 'an institution or society for the advancement of literature, art or science', bureau is 'an office or agency, especially one providing services for the public', centre is 'a place at which some specified activity is concentrated', institute is 'an organisation founded for particular work, such as education, promotion of the arts, or scientific research' and institution is a synonym for institute. In Xhosa, iziko is a 'fireplace'. In a traditional Xhosa hut, the fireplace is in the centre of the floor. In example 3 of Table 5 , we notice the repetitive use of iziko to refer to institute, centre, organization and association.

Table 5: academy/bureau/centre/institute/institution(s)/unit > i(ama)ziko

\begin{tabular}{|c|c|}
\hline Source text & Target text \\
\hline academy/bureau/centre/institute/ institution(s)/unit & i(ama)ziko 'fireplace(s) \\
\hline \multicolumn{2}{|l|}{ 1. academy DACST (1998) } \\
\hline $\begin{array}{l}\text { The International Eisteddfod of South Africa received funds for } \\
\text { infrastructure, as did the National Eisteddfod Academy. }\end{array}$ & $\begin{array}{l}\text { Umnyadala womculo wamazwe ngamazwe eMzantsi Afrika } \\
\text { wafumana inkxaso-mali yamalungiselelo, kanye njengokuba Iziko } \\
\text { Loqeqesho-mculo Likazwelonke lafumana. }\end{array}$ \\
\hline \multicolumn{2}{|l|}{ 2. bureau DACST (1998) } \\
\hline $\begin{array}{l}\text { The bureau is managed according to strategic goals formulated for } \\
\text { each year and the subsidy is allocated according to these goals. }\end{array}$ & $\begin{array}{l}\text { Iziko eli lilawulwa ngokweenjongo eziyilelwe umnyaka ngamnye } \\
\text { kwaye inkxaso-mali yabiwa ngokwezi njongo nayo. }\end{array}$ \\
\hline \multicolumn{2}{|l|}{ 3. institute /centre DACST (1998) } \\
\hline $\begin{array}{l}\text { The Institute is an internationally recognised research and informa- } \\
\text { tion centre (an autonomous, non-partisan organisation, registered } \\
\text { as an association not for gain). }\end{array}$ & $\begin{array}{l}\text { Iziko eli livunywa njengeziko lophando nenkcazelo ngamazwe } \\
\text { ngamazwe (iziko elizimeleyo, elingatyekelanga kwicala elithile, } \\
\text { nelibhaliswe njengeziko elingenzi ngeniso). }\end{array}$ \\
\hline \multicolumn{2}{|l|}{ 4. institutions DACST (1998) } \\
\hline $\begin{array}{l}\text { The investigation aims to establish how institutions, either individu- } \\
\text { ally or as components of the National System of Innovation, could } \\
\text { be restructured, reconfigured or resourced to meet broad national } \\
\text { goals. }\end{array}$ & $\begin{array}{l}\text { Injongo yolu phando kukuqinisekisa indlela anokwakhiwa ngayo } \\
\text { kwakhona, anokumiswa okanye anokubonelelwa ngayo la maziko, } \\
\text { nokuba linye okanye aluluhlu lweNkqubo yoBuzwe yoqambo, khona } \\
\text { ukuze abe nokufezekisa iinjongo zesizwe eziphangaleleyo. }\end{array}$ \\
\hline \multicolumn{2}{|c|}{\begin{tabular}{|l|l|} 
5. units Short Guide (1998) & \\
\end{tabular}} \\
\hline $\begin{array}{l}\text { This involves establishing service delivery units, managed along } \\
\text { commercial lines... }\end{array}$ & $\begin{array}{l}\text { Oku kuquka ukuseka amaziko okunikela ngenkonzo, maziko lawo } \\
\text { alawulwa njengamashishini,... }\end{array}$ \\
\hline
\end{tabular}

Iziko has acquired extended meanings such as 'headquarters' or 'seat of the legislature', 'administration', 'training or educational centre', 'an organization', 'business', even 'broadcasting corporation' as in 'South African Broadcasting Corporation' - Iziko loSasazo loMzantsi Afrika. Extended meanings of iziko from The greater dictionary of Xhosa (Pahl et al., 1989) are explained as follows: 


\begin{tabular}{|l|l|l|}
\hline Xhosa & English & Afrikaans \\
\hline $\begin{array}{l}\text { Isiseko, unozala, ikhayakhulu, isizinde, } \\
\text { okweendawo zolawulo eburhulumenteni, } \\
\text { umbutho namasebe awo, umzi wesithembu, } \\
\text { umthombo, ijelo apho zonke izinto ziphuma } \\
\text { khona, okweendaba, usasazo, ecaweni kwi- } \\
\text { mizi yoshishino }\end{array}$ & $\begin{array}{l}\text { headquarters or seat of the legislature, ad- } \\
\text { ministration, judiciary, church, an organiza- } \\
\text { tion, business, broadcasting corporation, etc. }\end{array}$ & $\begin{array}{l}\text { hoofkwartier van 'n regering, administrasie, } \\
\text { kerk, organisasie, sakeonderneming, ens. }\end{array}$ \\
$\begin{array}{l}\text { indawo ekufuthwa kuyo abantu, emfundweni, } \\
\text { emkhosini, kumashishini }\end{array}$ & $\begin{array}{l}\text { training or educational centre, e.g. for educa- } \\
\text { tion, business, the military, etc. }\end{array}$ & $\begin{array}{l}\text { sentrum, bv van opvoeding, nywerheid, } \\
\text { militêre opleiding, ens. }\end{array}$ \\
\hline
\end{tabular}

\section{campaign/project(s) $>i($ ama $)$ phulo}

In Xhosa, iphulo is 'a great hunting expedition'. This activity was taken seriously among the Xhosas. Satyo (1981:38) describes iphulo as follows:

Iphulo liqela elikhulu labantu abaya kuzingela. Lithatha ixesha elide kakhulu phaya ekuzingeleni, laye phambi kokuba liphume kuqalwe kwaziswe kwangethuba.

'Iphulo is a big group of people who go out to hunt. The group is engaged in this activity for a very long time and, before the group goes out, it is informed beforehand.'

A campaign is defined as 'a series of coordinated activities designed to bring about a particular result', and a project is 'a task requiring considerable concerted effort or a large undertaking' (Collins Concise Dictionary, 2001). Iphulo as a translation of campaign and project fits well in the following contexts.

Table 6: campaign/project(s) > i(ama)phulo

\begin{tabular}{|l|l|}
\hline Source text & Target text \\
\hline Campaign / project(s) & i(ama)phulo 'hunting expedition(s)' \\
\hline 1. campaign DACST (1998) & \\
\hline $\begin{array}{l}\text { A comprehensive media campaign was launched at the end of } \\
\text { October... }\end{array}$ & Iphulo lendaba eliqinileyo laqaliswa ekupheleni kuka-Okhthobha... \\
\hline $\mathbf{2 . 1}$ projects DACST (1998) & $\begin{array}{l}\text { Iphulo elisebenzisana neYunivesithi yase Wits licetyelwa unyaka } \\
\text { we-1998 ... }\end{array}$ \\
\hline $\begin{array}{l}\text { A joint project with the University of Witwatersrand is planned for } \ldots \\
\text { 2.2 projects Short Guide (1998) }\end{array}$ & \begin{tabular}{l} 
Amaphulo amatsha kufuneka aqhutywe kakuhle yaye alondolozwe... \\
\hline New projects must be properly operated and maintained...
\end{tabular} \\
\hline
\end{tabular}

\section{resource(s)/source(s )> um(imi)thombo}

The basic meaning of umthombo is 'fountain or spring'. A place or a person that is a source of help can be referred to as umthombo. Since resource can refer to 'a supply or source of aid or support', and source to 'any person, book, organization, etc. from which information, evidence is obtained' (Collins Concise Dictionary, 2001), umthombo is a suitable translation.

Table 7: resource(s)/ source(s) > um(imi)thombo

\begin{tabular}{|l|l|}
\hline Source text & Target text \\
\hline Resources/sources & imithombo 'fountains' \\
\hline 1. resources DACST (1998) & \\
\hline $\begin{array}{l}\text {...capturing human and physical capital resources serves as a deci- } \\
\text { sion support tool... }\end{array}$ & $\begin{array}{l}\text {...olutsala imithombo ephambili yoluntu namandla sisebenza } \\
\text { njengesixhobo soxhaso-sigqibo }\end{array}$ \\
\hline 2. sources DACST (1998) & $\begin{array}{l}\text { Imithombo yolwazi nobuchwepheshe, eyemveli, ethunyelwe nga- } \\
\text { manye amazwe kweli okanye edityanisiweyo; }\end{array}$ \\
\hline $\begin{array}{l}\text { Sources of knowledge and technologies, indigenous, imported or } \\
\text { blended; }\end{array}$ & \\
\hline
\end{tabular}




\begin{tabular}{|l|l|}
\hline 3. sources Short Guide (1998) & \\
\hline $\begin{array}{l}\text { Charges for services such as water, electricity and sewerage are the } \\
\text { largest sources of income. }\end{array}$ & $\begin{array}{l}\text { Imali yokuhlawulela iinkonzo ezifana namanzi, umbane nogutyulo } \\
\text { lwelindle zingumthombo omkhulu wengeniso. }\end{array}$ \\
\hline
\end{tabular}

In The Constitution of the Republic of South Africa (1996), resources is translated as izixhaso 'things for support'.

\section{resources > izixhaso}

- ST: A province must provide for itself any resources that it requires, in terms of a provision of its provincial constitution, ...

- TT: Iphondo kufuneka lizibonelele ngazo naziphi na izixhaso elizifunayo ngokommiselo okhoyo kumGaqoSiseko,...

Izixhaso is a noun derived from the verb -xhasa 'to support'.

\section{Using more familiar or common synonyms}

This strategy has been widely used by Xhosa translators when translating financial terms. Some financial terms can be referred to as 'unfamiliar', because they express concepts which were initially not part of the Xhosa culture. For example, wealth among the Xhosas was determined by the number of cattle one owns and not by money. The following words do differ slightly in one or two semantic features, but they are perceived as synonyms by Xhosa translators.

\section{cash/finance/funds/money > (i)imali}

According to The Penguin dictionary of international finance (Bannock \& Manser, 2003), cash is defined as 'money in tangible form, namely coins and banknotes in contrast to bank cheques and deposits'. Finance is 'the provision of money when and where required. Finance may be short term (usually up to 1 year), medium term (1-7 years) or long term'. Fund is 'a sum of money, as in an amount of savings handed to a stockbroker for investment and management'. Money is 'the means of facilitating the exchange of goods and services and the accumulation of financial wealth commonly recognizable as banknotes, coins and bank deposits'. The Xhosa translators did not draw a distinction between these terms.

Table 8: cash/finance/funds/money > (i)imali

\begin{tabular}{|l|l|}
\hline Source text & Target text \\
\hline Cash/finance/money & Imali 'money' \\
\hline 1. cash PanSALB (2001/2002) & \\
\hline Net cash from operating activities & Imali iyonke evela kwimisebenzi \\
\hline 2. finance Short Guide (1998) & \\
\hline There is a need to improve the system of finance. & Kukho intswelo yokuphucula inkqubo yemali. \\
\hline 3. funds Short Guide (1998) & \\
\hline Funds will be transferred directly to municipalities. & Iimali ziya kudluliselwa ngqo koomasipala. \\
\hline 4. money Short Guide (1998) & \\
\hline $\begin{array}{l}\text {...transfer of money from national to provincial and local govern- } \\
\text { ment }\end{array}$ & $\begin{array}{l}\text {...kukudluliselwa kwemali ukusuka kurhulumente wesizwe ukuya } \\
\text { kowamaphondo nolawulozidolophu }\end{array}$ \\
\hline
\end{tabular}

\section{income/revenue $>$ ingeniso}

According to the Collins dictionary of business (Pass, Lowes, Pendleton \& Chadwick, 1995), income refers to 'money received by individuals, firms and other organizations in the form of wages, salaries, rent, interest, commissions, fees and profit, together with grants, unemployment benefit, old-age pensions, etc.' Revenue means 
'money received by a firm from the sale of its output of goods or services or money received by government from taxation'. Looking at the above definition of revenue, ingeniso does not give the full meaning of revenue. It can be said that ingeniso as an equivalent of revenue is a less expressive word. The word ingeniso is derived from the verb -ngenisa 'cause to come in'. It is formed by suffixing the causative extension -is- to the basic stem -ngena 'come in' and the noun is formed by prefixing $i$ - to -ngenisa and changing the terminal vowel $-a$ into - $o$ hence ingeniso (something coming in).

Table 9: income/revenue > ingeniso

\begin{tabular}{|l|l|}
\hline Source text & Target text \\
\hline Income/revenue & Ingeniso 'income' \\
\hline 1. income Short Guide (1998) & \\
\hline $\begin{array}{l}\text { Charges for services - such as water, electricity and sewerage - are } \\
\text { the largest sources of income for most municipalities. }\end{array}$ & $\begin{array}{l}\text { Imali yokuhlawulela iinkonzo - ezifana namanzi, umbane nogutyulo } \\
\text { lwelindle - zingumthombo omkhulu wengeniso yoomasipala aban- } \\
\text { inzi. }\end{array}$ \\
\hline 2. income PanSALB (2001/2002) & $\begin{array}{l}\text { Izibonelelo ezivela kurhulumente nezinye ingeniso zithatyathwa } \\
\text { njengengeniso eqokelelweyo. }\end{array}$ \\
\hline $\begin{array}{l}\text { Government grants and other income are recognised as income on } \\
\text { an accrual basis. }\end{array}$ & $\begin{array}{l}\text { UmGaqosiseko (kwiSiqendu 214) uchaza ukuba oomasipala baya } \\
\text { kuba nelungelo "kwisahlulo esinobulungisa” sengeniso yesizwe. }\end{array}$ \\
\hline 3. revenue Short Guide (1998) & $\begin{array}{l}\text { Ingeniso eqokelelweyo: Izibonelelo ezivela kurhulumente nenye } \\
\text { ingeniso zithatyathwa njengengeniso eqokelelweyo. }\end{array}$ \\
\hline 4. revenue/income PanSALB (2001/2002) \\
\hline $\begin{array}{l}\text { Revenue recognition: Government grants and other income are } \\
\text { recognised as income on the accrual basis. }\end{array}$
\end{tabular}

\section{remuneration/salary > umvuzo}

According to the Collins dictionary of business (Pass et al., 1995), remuneration is 'a pay or reward to workers and managers for their labour services, in the form of wages, salaries and bonuses' and salary is 'a payment made to employees for the use of their labour'. Salaries are expressed in an annual sum, a portion of which is paid to the employee each month. Both remuneration and salary have to do with paying someone for his/her labour, but they differ slightly because salaries are paid on a monthly basis whereas remuneration involves payment for the service rendered at the time. The word umvиzo is formed from the verb -vuza '(to) reward'.

Table 10: remuneration/salary > umvuzo

\begin{tabular}{|l|l|}
\hline Source text & Target text \\
\hline remuneration /salary & Umvuzo 'salary' \\
\hline 1. remuneration PanSALB (2001/2002) & \\
\hline Auditor's remuneration & Umvuzo woMphicothi \\
\hline 2. salary PanSALB (2001/2002) & \\
\hline $\begin{array}{l}\text {... staff shall receive an annual pension allowance equal to 17.5\% of } \\
\text { his or her annual salary }\end{array}$ & $\begin{array}{l}\text {...abasebenzi banako ukufunyaniswa isibonelelo somhlalaphantsi } \\
\text { esilingana ne-17.5\% somvuzo } \text { wonyaka }\end{array}$ \\
\hline
\end{tabular}

In The greater dictionary of Xhosa (Pahl et al., 1989), -vuza means '(to) pay wages or a salary', 'remunerate', 'reward'. The meaning of umvuzo from The greater dictionary of Xhosa (Pahl et al., 1989) is given as:

\begin{tabular}{|l|l|l|}
\hline Xhosa & English & Afrikaans \\
\hline $\begin{array}{l}\text { uku-vuza nz/v } \\
\begin{array}{l}\text { ukuhlawula (umntu) ngenkonzo ayenzileyo } \\
\text { okanye umsebenzi awenzileyo }\end{array}\end{array}$ & pay wages or a salary, remunerate, reward \\
$\begin{array}{l}\text { wamvuza ngethokazi lenkomo ngomsebenzi } \\
\text { awenzileyo }\end{array}$ & $\begin{array}{l}\text { he rewarded his friend with a heifer for his } \\
\text { services }\end{array}$ & $\begin{array}{l}\text { hy het sy vriend met 'n vers vir sy dienste } \\
\text { vergoed }\end{array}$ \\
\hline
\end{tabular}


In The Constitution of the Republic of South Africa (1996) remuneration is translated as intlawulo 'payment'.

remuneration > intlawulo

- ST: anyone who is appointed by, or is in the service of, the municipality and receives remuneration for that appointment

- TT: kwakhe nabani na oqeshwe, okanye okwinkonzo ethile kamasipala kwaye efumana intlawulo ngoko kuqeshwa

\section{levy/rates/tax > irhafu}

According to the Collins dictionary of business (Pass et al., 1995), tax is 'a levy imposed by the government on goods and services (indirect tax) and the income and wealth of persons and businesses (direct tax)'. From the above definition, tax and levy appear to be synonymous.

Table 11: levy / rates / tax > irhafu

\begin{tabular}{|l|l|}
\hline Source text & Target text \\
\hline levy/rates/tax & irhafu 'tax' \\
\hline 1. levy Short Guide (1998) & \\
\hline $\begin{array}{l}\text { Part of the national fuel levy may be given to local government for } \\
\text { road maintenance. }\end{array}$ & $\begin{array}{l}\text { Inxalenye yerhafu yamafutha ezithuthi inokunikwa ulawulozidolo- } \\
\text { phu ngenjongo yokugcina iindlela zisemgangathweni. }\end{array}$ \\
\hline 2. rates Short Guide (1998) & \\
\hline $\begin{array}{l}\text {... the period of valuation and ways of assisting those who cannot } \\
\text { afford to pay full rates. }\end{array}$ & $\begin{array}{l}\text {...ixesha lokubeka ixabiso, neendlela zokuncedisa abo bangenakho } \\
\text { ukuhlawula iirhafu ngokupheleleyo. }\end{array}$ \\
\hline 3. tax Short Guide (1998) & $\begin{array}{l}\text { Ezinye iindlela zokukhulisa ingeniso yoomasipala abangamahl- } \\
\text { wempu- ezifana nerhafu yomiwomhlaba emaphandleni-ziya } \\
\text { kuphononongwa. }\end{array}$ \\
\hline $\begin{array}{l}\text { Other ways to increase revenue for poorer municipalities - such a } \\
\text { property tax for rural areas - will be investigated. }\end{array}$ \\
\hline
\end{tabular}

In The Constitution of the Republic of South Africa (1996), rates, tax and levy are translated as follows: rates > irhafu yepropati

taxes $>$ iirhafu

levies > iintlawuliso

- ST: the imposition of rates and other taxes, levies and duties;

- TT: umiselo lwerhafu yepropati nezinye iirhafu neentlawuliso neentlawulelo-zinto.

Rates, tax and levy are treated as synonyms in Xhosa. See the following definition of irhafu from The greater dictionary of Xhosa (Pahl et al., 1989). In The greater dictionary of Xhosa (1989) the meaning of irhafu is given as:

\begin{tabular}{|c|c|c|}
\hline Xhosa & English & Afrikaans \\
\hline $\begin{array}{l}\text { i-rhafu b/n } 9 / 10<\text { Du gave: iimali zemim- } \\
\text { iselo karhulumente ebantwini ekufuneka } \\
\text { bezihlawule ngamaxesha athile }\end{array}$ & $\begin{array}{l}\text { tax, e.g. income tax; rates, e.g. rates paid } \\
\text { by property owners in a town, or road rates; } \\
\text { (derived from Dutch: 'gave'/'gift', a word } \\
\text { used by the first missionaries among the } \\
\text { Khoikhoin at Bethelsdorp to denote the con- } \\
\text { tributions of members to the church). }\end{array}$ & $\begin{array}{l}\text { belasting, bv inkomste-, eiendoms- of wiel- } \\
\text { belasting; afgelei van die Hollandse gawe, } \\
\text { gebruik deur die eerste sendelinge onder } \\
\text { die Khoikhoin te Bethalsdorp kerklidmate se } \\
\text { bydraes. }\end{array}$ \\
\hline
\end{tabular}

The translations of the above financial terms are in line with the definitions found in the Collins dictionary of business (Pass et al., 1995) and The Penguin international dictionary of finance (Bannock \& Manser, 2003). The dictionaries provide a basic definition followed by an explanation of a particular concept which leads, through cross-references, to related terms. The two financial dictionaries are helpful to the translator as they clarify the use 
of synonyms in the target language (TL) for different terms in the source language (SL). Xhosa does not draw a clear distinction between the meanings of the terms discussed above.

\section{Conclusion}

Firstly, it can be stated that the hot word function in ParaConc has been used successfully to verify the lexical simplification strategies found in the English-Xhosa parallel texts under study. There were very few occurrences where there were not enough matches to support the findings (cf. Appendix). In such cases concordance lines can be used for validation. Secondly, since Xhosa is still lacking in technical terms, and there are very limited resources available to the Xhosa translator at present, the analysis conducted in this article shows how the Xhosa translators employed simplification strategies to communicate the source message to the target reader. It has also been observed that English has more specific words as compared to Xhosa. This can be attributed to the fact that English has a greater number of words than most languages, and has derived and adopted words from other languages (Barnhart \& Barnhart, 1992; Aitchison, 1994). On the other hand, African languages in general and Xhosa in particular, have so far rarely been used in scientific, technical, economical and other related fields in South Africa. Pahl et al. (1989:xxxii) concur with the above viewpoint when they write, 'Xhosa has not yet extended its roots deeply [own emphasis] into the soil of scientific and technological fields'. Lastly, this article gives the reader an idea about the role played by translation in the development of the African languages of South Africa. As a number of official documents are constantly being translated from English into the various African languages, this means, new words are added to the vocabulary of these languages through translation, and some general words are being used as language for specific purposes.

\section{Appendix}

\section{'Hot word' findings}

1. Hot word search of inkqubo: In the list of hot words found in The 1997 DACST Annual Report, 'programme' ranks high at 13.75, followed by 'process' at 7.54, and 'policy' at 6.18. Most instances of inkqubo in the Short Guide refer to 'system' ranking at 36.74 and 'programme' at 19.76 .

2. Hot word search of indlela: In the Short Guide, 'system' is the only relevant hot word in the list, and ranks very high at 62.19. In The 1997 DACST Annual Report the hottest word is 'strategy/strategies' at 7.59, followed by 'system/ systems' at 6.12. It is worth noting that the singular and plural forms of a word are treated as one candidate, hence equal frequency.

3. Hot word search of umgaqo: In The 1997 DACST Annual Report 'policy' ranks at 53.92.

4. Hot word search of umbutho: In The 1997 DACST Annual Report the hottest word in the list is 'body' at 10.96, followed by 'organizations/organization' at 9.60, and 'association' at 9.18. The hot word search of imibutho in the Short Guide, shows 'organizations' at 16.59 and 'bodies' at 12.40.

5. Hot word search of iziko: The hot word search of iziko in The 1997 DACST Annual Report shows the following results: 14.25 'bureau', 9.47 'centre', 7.74 'academy', 7.13 'institute'.

6. The hot word search of iphulo: In The 1997 DACST Annual Report both 'campaign' and 'project' are found and 'campaign' ranks higher at 14.95 than 'project' at 13.69.

7. Hot word search of imithombo: Due to the low frequency of 'resources/sources', there were not enough matches to verify the findings.

8. Hot word (parallel) search of cash/imali: In the PanSALB Financial Statements 'cash'/imali ranks at 126.80. The following are the results from the Short Guide: 29.45 'funds', 29.29 'finance/finances'.

9. Hot word search of ingeniso: In the Short Guide, 'revenue' ranks at 69.09.

10. Hot word search of umvuzo: Not enough matches for 'remuneration/salary' to support the findings.

11. Hot word search of irhafu: The following are the results from the Short Guide: 53.63 'levies/duties', 14.98 'rates'. 


\section{References}

Aitchison, J. 1994. Cassell guide to written English. London: BCA.

Baker, M. 1992. In other words: A coursebook on translation. London: Routledge.

Baker, M. 1996. Corpus-based translation studies: The challenges that lie ahead, in Terminology, LSP and translation studies in language engineering: In Honour of Juan C. Sager, edited by H. Somers. Amsterdam: John Benjamins:175-186.

Bannock, G. \& Manser, W. 2003. The Penguin dictionary of international finance. London: Penguin.

Barlow, M. 1995. Paraconc: A concordancer for parallel texts (Reprinted from Computers and Texts.). USA: Rice University. http://www.raymond.gallery.net/Barlow. Accessed on 2008/11/20.

Barlow, M. 2002. ParaConc: Concordance software for multilingual parallel corpora. http://www.mt-archive.info/ LREC-2002-Barlow. Accessed on 2008/10/08.

Barnhart, C.L. \& Barnhart, R.K. 1992. The world book dictionary. Chicago: West Monroe.

Collins Concise Dictionary. 2001. Glasgow: Harper Collins.

Department of Arts, Culture, Science \& Technology (DACST). 1998. Annual Report 1997. Pretoria: The Government Printer.

Department of Constitutional Development. 1998. A short guide to White Paper on local government. Pretoria: Arcadia.

Laviosa-Braithwaite, S. 1996. The English comparable corpus (ECC): A resource and methodology for the empirical study of translation. Unpublished Ph.D. thesis. Manchester: Dept of Language Engineering, UMIST.

Laviosa-Braithwaite, S. 1997. Investigating simplification in an English comparable corpus of newspaper articles, in Transferre Necesse Est. Proceedings of the 2nd international conference on current trends in studies of translation and interpreting, edited by K. Klaudy \& J. Kohn. Budapest: Scholastica:531-540.

Mini, B.M., Tshabe, S.L., Shoba, F.M. \& van der Westhuizen, P.N. 2003. The greater dictionary of Xhosa (Volume 2). Alice: University of Fort Hare.

Moropa, C.K. 2005. An investigation of translation universals in a parallel corpus of English-Xhosa texts. Unpublished D. Litt et Phil. thesis. Pretoria: University of South Africa.

Moropa, K. 2007. Analysing the English-Xhosa parallel corpus of technical texts with ParaConc: A case study of term formation processes. South African Linguistics and Applied Language Studies 25(2):183-205.

Pahl, H., Pienaar, A.M. \& Ndungane, T.A. 1989. The greater dictionary of Xhosa (Volume 3). Alice: University of Fort Hare.

Pan South African Language Board. 2002. Financial statements 2001/2002. Pretoria: Arcadia.

Pass, C., Lowes, B., Pendleton, A. \& Chadwick, L. 1995. Collins dictionary of business. Glasgow: Harper Collins.

Republic of South Africa. 1996. UmGaqo-siseko weRiphablikhi yoMzantsi Afrika. Pretoria: Government Printers. Republic of South Africa. 1996. The constitution of the Republic of South Africa. Pretoria: Government Printers. Satyo, S.C. 1981. Uphengululo lwesiXhosa. Pretoria: De Jager-Haum Publishers.

The Penguin English Dictionary. 1985. London: Longman. 